\title{
Razor Clams (Class Bivalvia) of Kuala Selangor, Malaysia: Morphology, Genetic Diversity and Heavy Metal Concentration
}

\author{
RUHANA HASSAN $*^{1} \&$ DEVAGI KANAKARAJU ${ }^{2}$ \\ ${ }^{1}$ Department of Aquatic Science, ${ }^{2}$ Department of Chemistry, Faculty of Resource Science and Technology, Universiti \\ Malaysia Sarawak, 94300 Kota Samarahan, Sarawak, Malaysia
}

\begin{abstract}
Razor Clam (Bivalvia) could be easily identified as having two long, narrow shell valves connected by hinges, two siphons and one strong foot. It plays important role in ecological services besides providing food and extra income for the coastal communities. As filter feeder, razor clam is a good indicator for heavy metal contamination in aquatic environments. In Selangor, razor clam is locally known as 'siput buluh', yet, there is no proper scientific documentation on this species. This short study was carried out to assess the morphology of razor clams in Selangor for species identification and to sequence the Cytochrome Oxidase I (COI) gene for determination of its genetic diversity. Heavy sea traffics occurred in the sea near to the mudflat where razor clams were abundantly found has raised question whether razor clams were safe to be consumed. Therefore, this study is also designed to determine the level of selected heavy metals concentration in different body parts of razor clams. Based on selected morphometric and meristic data, razor clams of Kuala Selangor obtained during this study were Solen sarawakensis although many individuals displayed darker outer shell colouration and slightly thicker, longer and heavier shells. Based on analyses of putative COI gene sequences of approximately $677 \mathrm{bp}$, there was a strong genetic divergence $(11.7 \%)$ between $S$. sarawakensis inhabiting Kuala Selangor and Kuching Bay, Sarawak suggesting that although both razor clams were very similar morphologically, they could actually be two different species. Tissues of razor clams sampled from mudflat area in Kuala Selangor showed high concentration of Fe $(146.50 \mathrm{mg} / \mathrm{kg})$ and $\mathrm{Mn}(94.00 \mathrm{mg} / \mathrm{kg})$. Other heavy metal elements namely $\mathrm{Cr}(42.50 \mathrm{mg} / \mathrm{kg})$ and $\mathrm{Cd}(33.00 \mathrm{mg} / \mathrm{kg})$ were also recorded during this study, occurring mainly in the shells. Traces of $\mathrm{Hg}$ were also detected, and its concentration did not differ much among the different parts analyzed.
\end{abstract}

Keywords: Razor clam, morphology, COI gene, heavy metal

\section{INTRODUCTION}

Razor clams are members of Class Bivalvia, characterized by two long, narrow shell valves gaping at both ends but connected by hinges, two siphons and one strong foot. In addition, each species displays different shell outlines as well as arrangement of the adductor scars and pallial muscle scars (Cosel 1990). Local people in Malaysia address these organisms by various local names as different dialects are applied (Hassan \& Laiping 2008), for example Kuchingites called them 'ambal', local people of Kuala Selangor called them 'siput buluh' while in Sabah they are known as 'pahatpahat'. Hung \& Hassan (2007) reported that there are three species of razor clams coexisting in Kuching Bay Sarawak namely Solen regularis, $S$. lamarckii and $S$. sarawakensis. Razor clams prefer intertidal

*Corresponding author: hruhana@frst.unimas.my sandy beaches or sandy bars, or mudflat areas (Hassan et al. 2007). Razor clams in Kuching Bay, Sarawak for example could be found in abundance during October to February coinciding with the occurrence of the lowest low tides during the day which are also linked with the degree of mudflat exposure (Rahim \& Tan 2008); the bigger mudflat areas exposed during low tide, the more harvesting activities could be carried out thus more razor clams will be collected. Commercial harvesting is an important extra source of income for the local inhabitants during this period hence the problem of overharvesting is unavoidable (Hassan et al. 2007).

Razor clams are bivalves and they are filter feeders (Pechenik 2000) so they play important role in the complex coastal food web as well as actively involved in ecological services. Bivalves are commonly used in environmental monitoring studies as they provide accurate 
information on the impacts and bioavailability of pollutants. These organisms lived buried in sediment and capable to accumulate high concentrations of heavy metals in tissues as they are filter-feeders. Numerous studies have been carried out to determine heavy metal levels in tissues and other organs such as kidney, shell, gills, mantle and foot of clams. Accumulation patterns of $\mathrm{Cd}, \mathrm{Cu}$ and $\mathrm{Zn}$ in different tissues of clam Tridacna crocea sampled from the Torres Strait area, Australia varied as kidney>gills $>$ mantle $>$ muscle (Duquesne \& Coll 1995). Rayment \& Barry (2000) reported that kidneys of giant clams Tridacna maxima contained heavy metals from 2 (for $\mathrm{Zn}$ ) to 2780 (for $\mathrm{Ni}$ ) times higher than corresponding concentrations in adductor muscles. Clam Vesicomya gigas from Guaymas basin, California showed higher metal levels in gills compared to other tissues. This could be due to the gills of the clams include particles enriched in metals (RuelasInzunza et al. 2000). The factors known to influence the heavy metals accumulation in bivalves include bioavailability, environmental conditions, season of sampling, size and reproductive cycle (Boyden \& Phillips 1981). Kumari et al. (2006) claimed that significant differences in metal concentrations were recorded among tissues of clam Paphia malabarica. They also reported that many factors could influence metal concentrations in clams, for example $\mathrm{pH}$ and salinity, besides increased in the precipitated form of metals in the water column coupled with higher rate of filtration.
In Sarawak, studies on razor clams including population density, ecology, taxonomy, genetic studies, reproduction, socio economic (e.g. Hassan et al. 2007; Hung \& Hassan 2007; Hassan \& Laiping 2008; Rahim \& Tan 2008; Rinyod \& Rahim 2011) had been carried out. However, information about razor clams in Peninsula Malaysia, particularly in Selangor is rather limited, although razor clams could be found in abundance and being consumed by local people as well as become part of hotels and restaurants menus. Besides that, mudflat in Kampung Kelanang, where majority of razor clams were harvested, was within the area of heavy sea traffics, mainly involved in transporting scrap metals from other parts of Selangor. This has triggered question on how safe is the razor clams harvested in this area, to be consumed by human.

This paper describes findings in terms of taxonomy based on morphological and molecular data of razor clams collected from Kuala Selangor. In addition, this paper also reports on the concentration of metals in various parts namely gill, foot, siphon, tissue and shell of razor clam in order to provide information on the accumulation sites of metals and the safety level of razor clams from Kuala Selangor for human consumption.

\section{MATERIALS \& METHODS}

Collection of razor clams was carried out in August 2007 on mudflats near Kampung Kelanang, Kuala Selangor (N1 ${ }^{\circ}$ 02'47.186", E110 23.354") (Figure 1). This mudflat area

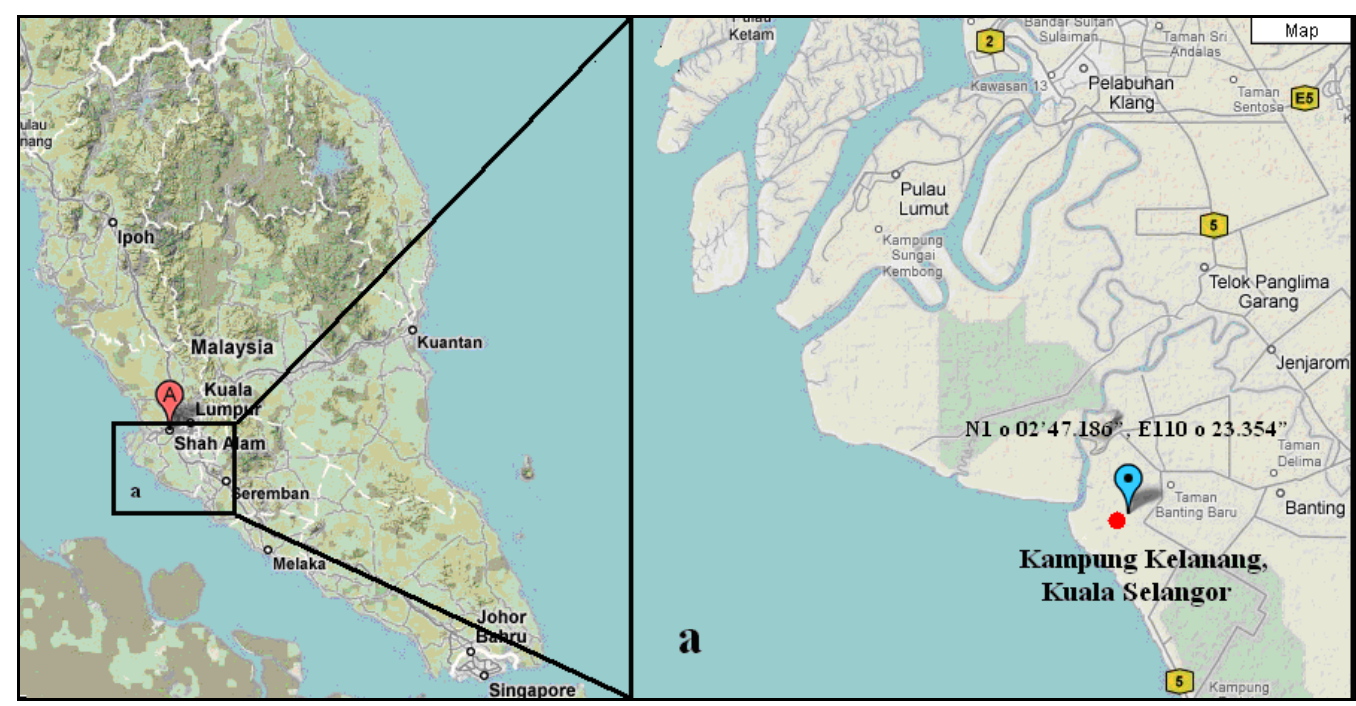

Figure 1. Map showing location of razor clams collection in Selangor during this study (Source: map.google.com.my). 
was chosen as study site due to the continuous presence of fleet of ships and barges involve in trading of the recycling scrap metals e.g. irons and other metals. In addition, a relatively large recycling metal factory present nearby, thus it is likely that contamination of heavy metal occurs in this area.

Approximately 30 individuals of razor clams were collected from this area with help of local people who used custom-made 'tempuling', a long arrow shape aluminum stick to directly stab the in between shell valves of razor clams and later pulled out of their burrows. All specimens were kept cool and transported back to the laboratories in the Faculty of Resource Science and Technology, Universiti Malaysia Sarawak. In order to determine the taxonomy, detail morphological assessment was carried out according to guidelines by Cosel (1990), Lamprell \& Healy (1998) and Abbott \& Dance (1982) and Oliver (1992).

For molecular work, razor clams' foot tissues were cut with clean scalpel blades, and each individual specimen was put into separate eppendorf tubes with appropriate labels and disposed in $-20^{\circ} \mathrm{C}$ freezer for storage. The total genomic DNA extraction was carried out using modified CTAB method (Grewe et al. 1993). Polymerase Chain Reaction (PCR) to amplify Cythochrome Oxidase 1 (COI) gene followed modification to protocols suggested by Chen $e t$ al. (2005), using primers RCOIA (5'-GGT CAA CAA ATC ATA AAG ATA TTG G-3') and RCOIB (5'-TAA ACT TCA GGG TGA CCA AAA AAT CA-3'). Amplification was carried out on BIO-RAD (MyCycler) PCR machine. Optimization of PCR conditions was carried out in a $25 \mu \mathrm{L}$ reaction mixture containing $1 \mu \mathrm{L}$ DNA ( 15-20 ng), $1 \mathrm{U} \mathrm{Taq}$ polymerase (Fermentas), $2.5 \mu \mathrm{L}$ of $10 \mathrm{x}$ PCR buffer (Fermentas), $2.0 \mu \mathrm{L}$ of $1.5 \mathrm{mM}$ magnesium chloride $\left(\mathrm{MgCl}_{2}\right), 2.5 \mu \mathrm{L}$ of 0.2 $\mathrm{mM}$ dNTPs (Fermentas) and $1.0 \mu \mathrm{l}$ of each primer $(5 \mu \mathrm{M})$. Amplification was achieved by 4 minutes at $94^{\circ} \mathrm{C}$ for initial denaturation, followed by 30 cycles of denaturation $\left(94^{\circ} \mathrm{C}, 2\right.$ minutes), annealing $\left(48^{\circ} \mathrm{C}, \quad 1\right.$ minute), extension $\left(72^{\circ} \mathrm{C}, 1\right.$ minute) and final elongation $\left(72^{\circ} \mathrm{C}, 5\right.$ minutes). PCR products were then purified using Promega Purification Kit according to manufacturer's instruction then sent to a private laboratory $\left(1^{\text {st }}\right.$ BASE, Selangor, Malaysia) for sequencing using the
ABI PRISM BigDye ${ }^{\circledR}$ Terminator v3.0 kit for both forward and reverse strands. The sequences obtained were retrieved by using CHROMAS version 1.45 (MacCarthy 1996), which then subjected to BLAST search (Altschul et al. 1990). All sequences were then aligned using CLUSTALX version 1.81 for windows (Thompson et al. 1997). Maximum Parsimony (MP) phylogenetic tree was constructed using MEGA 4.0 (Tamura $e t$ al. 2007). In addition, Pairwise distance calculations were conducted using the twoparameter model of Kimura (1980) to estimate the genetic distances among the $S$. sarawakensis individual using MEGA 4.0 (Tamura et al. 2007).

For heavy metal studies, samples which had been kept in freezer at $-20^{\circ} \mathrm{C}$ were thawed and washed with tap water and deionized water to remove unwanted materials. Later, each sample was separated into 5 groups namely gill, foot, siphon, tissue and shell, with appropriate labels. Then, all samples were transferred into glass flask and freeze-dried for 48 hours using a freeze dryer LABCONCO 775032-18L. The dried samples were ground to fine powder with a porcelain pestle and mortar. Powdered samples were stored in sealed plastic bags with appropriate labels and kept in a desiccator until further analysis.

Acid digestion technique was performed according to Lau et al. (1998). Exactly $0.5 \mathrm{~g}$ tissues, gill, siphon and foot samples were digested with $6 \mathrm{~mL}$ of concentrated nitric acid $\left(\mathrm{HNO}_{3}\right)$ and $1 \mathrm{~mL}$ of hydrogen peroxide $(30 \%$ $\mathrm{H}_{2} \mathrm{O}_{2}$ ) in a hot plate at $29^{\circ} \mathrm{C}$. A total of 0.5 grams of dried shell sample was digested with $2 \mathrm{~mL}$ concentrated nitric acid, $5 \mathrm{~mL}$ concentrate hydrochloric acid $(37 \% \mathrm{HCl})$ and $1 \mathrm{~mL}$ of hydrogen peroxide $\left(30 \% \quad \mathrm{H}_{2} \mathrm{O}_{2}\right)$. Sample digestions were carried out for 2 hours. The final solutions were filtered and diluted to $25 \mathrm{~mL}$ using deionized water in a volumetric flask.

The extracts were analyzed using Atomic Absorption Spectrophotometer (FAAS) Thermo Scientific ICE 3500 for Cd, Mn, Cr and $\mathrm{Fe}$ whereas Flow Injection Mercury System (FIMS) Perkin Elmer 400 was used to measure $\mathrm{Hg}$. 


\section{RESULTS \& DISCUSSION}

Based on morphological data including measurements taken from the outline and arrangement of adductor scar, pallial muscle scar and pallial line pattern as suggested by Hung \& Hassan (2007), razor clams of Kuala Selangor are Solen sarawakensis (Figure 2) although many individuals displayed darker outer shell colouration and slightly thicker, longer and heavier shells compared to those of S. sarawakensis from Kuching Bay, Sarawak. In this communication, $S$. sarawakensis from Kuching bay Sarawak and Kuala Selangor will be referred to as $S$. sarawakensis Type I and Type II, respectively. S. sarawakensis Type I had recorded total shell length as $97 \pm 1.5 \mathrm{~cm}$ and $13.6 \pm 0.2 \mathrm{~cm}$ shell width whereas $S$. sarawakensis Type II had total shell length as $106.8 \pm 6.3 \mathrm{~cm}$ and $15.4 \pm 0.9 \mathrm{~cm}$ shell width.

Several optimizations had been carried out on CTAB protocol (Grewe et al. 1993) used in this study, and eventually good total genomic DNA extraction products from razor clam foot tissues were obtained. Partial putative COI gene of approximately $677 \mathrm{bp}$ had been sequenced, and they were $T$ rich, comprised on average $18 \% \mathrm{~A}, 14.2 \% \mathrm{C}, 44 \% \mathrm{~T}$ and $23.8 \%$ G. Representatives of sequences had been deposited in GenBank National Centre for Biotechnology Information (NCBI) with accession numbers FJ662782, FJ662783 and FJ662784.

Detailed analyses of $\mathrm{COI}$ gene sequences obtained showed that strong genetic divergence of $11.7 \%$ based on COI gene was recorded (Table 1), if compared to $S$. sarawakensis Type I which were found in Kuching Bay Sarawak. Therefore, one may suggest that although both razor clams were very similar morphologically, they could actually be a different species as Bradley \& Baker (2001) suggested genetic distance value of more than $11 \%$ is an indicative of specific recognition. In Figure 3, S. sarawakensis Type II, form a monophyletic grouping with high bootstrap value (98\%), and act as sister taxon to $S$. sarawakensis Type I, whom also formed another clade. The result of monophyly of these two groups respectively, further supported that most likely $S$. sarawkensis Type I (Sarawak) and S. sarawakensis Type II (Selangor) are indeed two different species.

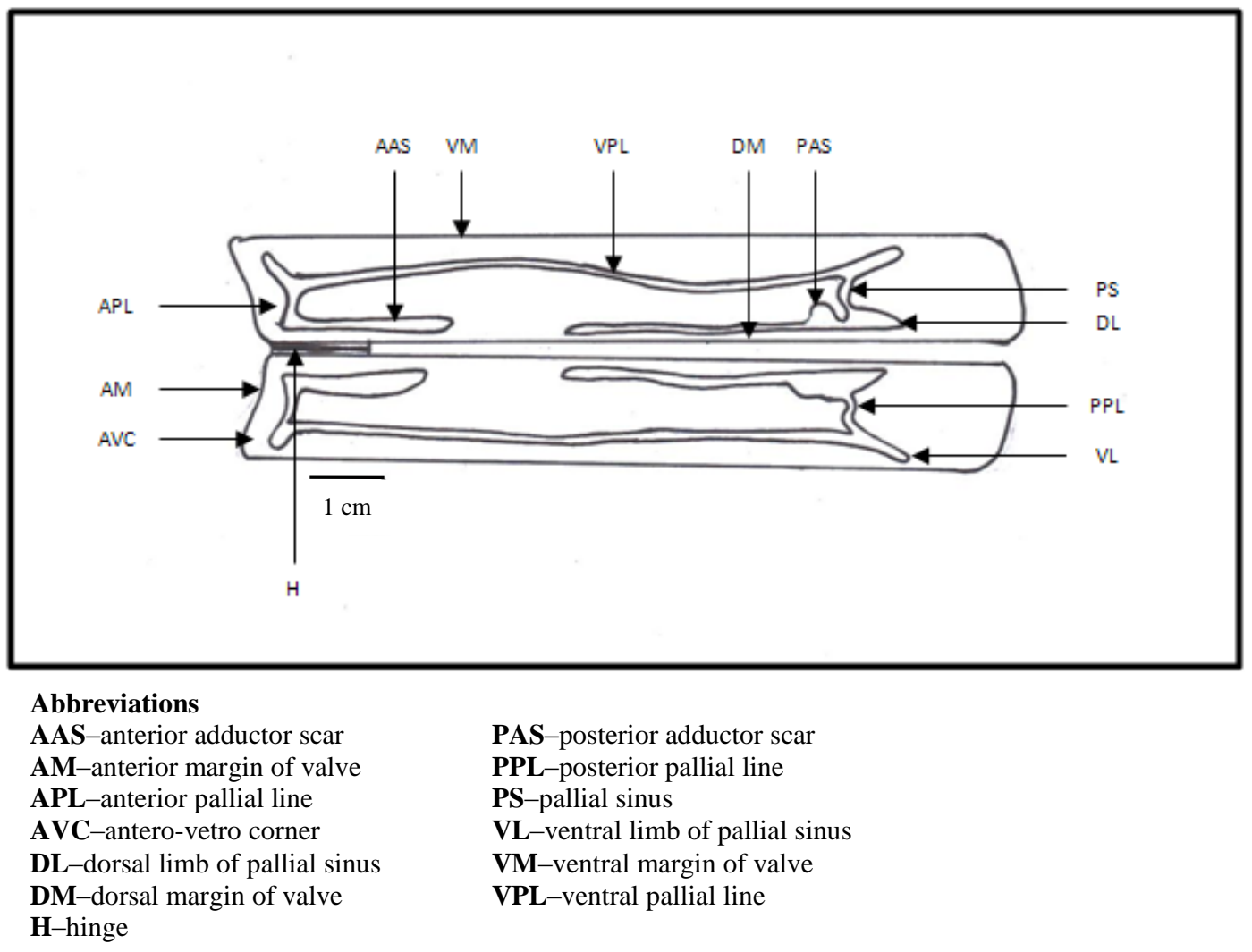

Figure 2. Outline and arrangement of adductor scar, pallial muscle scar and pallial line pattern of Solen sarawakensis. 
Table 1. Summary of pairwise genetic distance value (\%) among Solen spp. based on COI gene sequences.

\begin{tabular}{llllll}
\hline & Species & 1 & 2 & 3 & 4 \\
\hline 1 & Solen regularis & 0 & & & \\
2 & S. lamarki & 17.2 & 0 & & \\
3 & S. sarawakensis Type I (Sarawak) & 17.1 & 22.2 & 0 & \\
4 & S. sarawakensis Type I (Selangor) & 16.8 & 21.8 & 11.7 & 0 \\
\hline
\end{tabular}

Although $\mathrm{CO} 1$ gene sequences showed genetic divergence value of $11.7 \%$ between $S$. sarawakensis Type I and S. sarawakensis Type II, this value is just slightly above the thresh hold level of $11 \%$ (Bradley \& Baker 2001). Further studies need to be done to determine conclusively whether $S$. sarawakensis clams from Kuching Bay and Kuala Selangor really belong to one or two species. Among the studies that could be done are: (i) sequencing other fast evolving genes such as $C y t b$ gene and Internal Transcribe Spacer region (ITS), (ii) more comprehensive data analysis on the genetic data collected, to further understand the genetic structure of razor clams in both areas (iii) include more razor clam samples in the analysis, and (iv) sampling exercise should involve wider geographical areas.

Table 2 depicts the average concentration of heavy metals levels in different tissues of razor clam. In general, the results demonstrated different capacity of metals accumulation in the tissues analyzed due to bioavailability of metals and the storage or uptake capacity of different organs (Duquesne $\&$ Coll 1995). The essential elements, Fe and $\mathrm{Mn}$ were found in elevated levels in razor clam samples. These essential elements are important in metabolic and biological activities and can be found in abundance in nature. Tissues of razor clam demonstrated better capacity to accumulate $\mathrm{Fe}$ and $\mathrm{Mn}$ compared to other body parts.

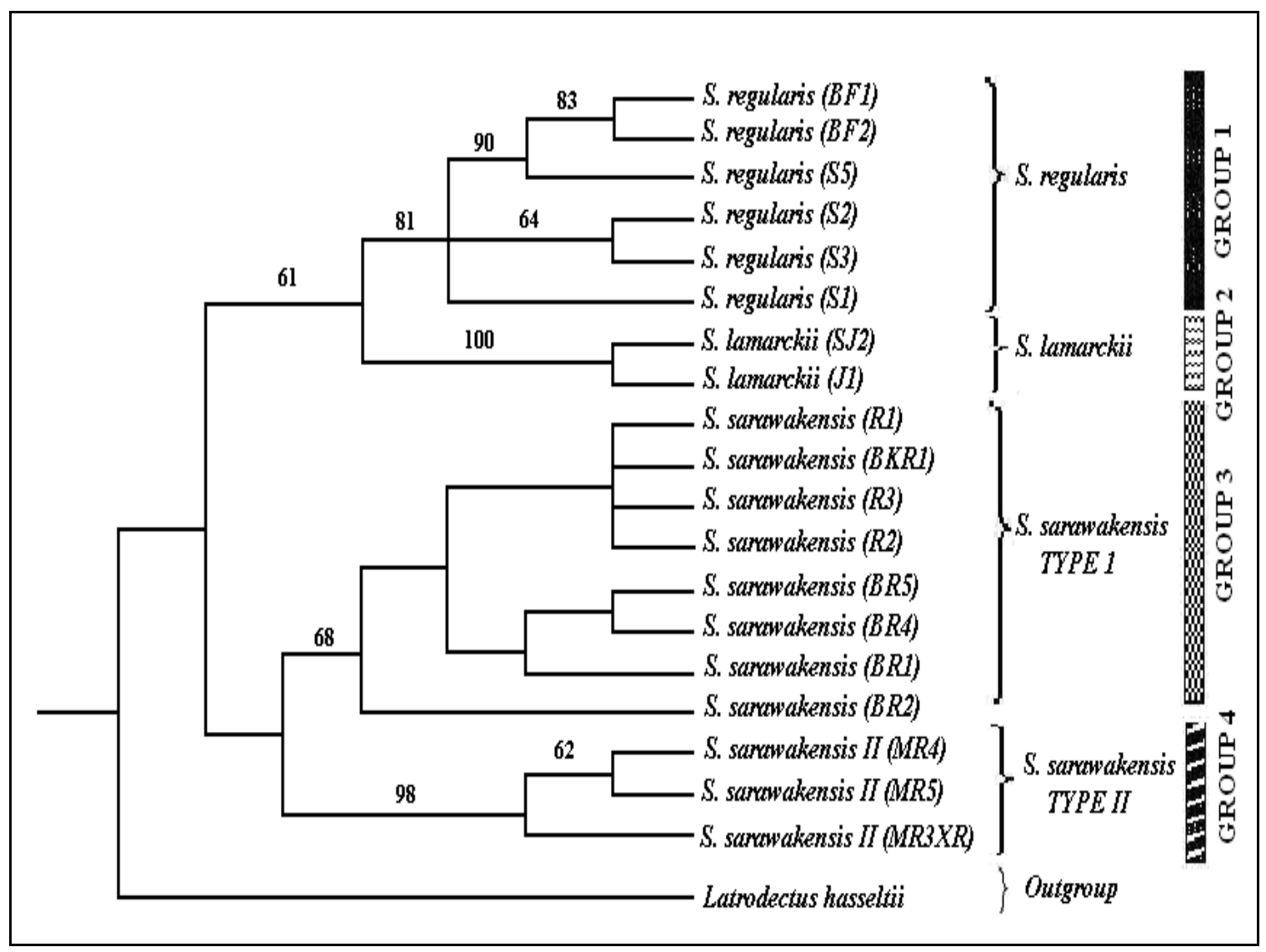

Figure 3. Maximum Parsimony phylogenetic tree showing relationships between individuals of Solen spp. based on COI gene analysis. Both groups of S. sarawakensis (Type I from Sarawak and Type II from Kuala Selangor) are reciprocally monophyletic, forming two separate clades. 
The similar trend was observed by Khalid \& Mohamed (2005) who examined clams $P$. undulata and $G$. pectinatum from Egypt. Manila clam, Ruditapes philippinarum obtained from west coast of Korea also indicated elevated levels of $\mathrm{Mn}$ in its tissue ( $\mathrm{Ji}$ et al. 2006). However, vent clam, Vesicomya gigas sampled from Gulf of California showed low amounts of Mn (7-18 $\mu \mathrm{g} / \mathrm{g})$ but high amounts of $\mathrm{Fe}(196-403 \mu \mathrm{g} / \mathrm{g})$ in its tissue. In this study, overall comparison of heavy metal concentrations in different parts of the razor clam resulted in a pattern of decreasing order: $\mathrm{Fe}>\mathrm{Mn}>\mathrm{Cr}>\mathrm{Cd}>\mathrm{Hg}$. The maximum permissible levels for $\mathrm{Fe}$ and $\mathrm{Mn}$ were not available by both guidelines as shown in Table 1. The maximum tolerable daily intake (MTDI) of $\mathrm{Fe}$ and $\mathrm{Mn}$ prescribed by JECFA (2000) are $0.8 \mathrm{mg} / \mathrm{kg}$ and $0.4-10 \mathrm{mg} / \mathrm{kg}$, respectively.

In this study, razor clam shell accumulated the highest amount of $\mathrm{Cd}(33.00 \mathrm{mg} / \mathrm{kg})$ when compared with other parts and the least amount of Cd occurring in tissue $(17.50 \mathrm{mg} / \mathrm{kg})$. The concentrations of $\mathrm{Cd}$ in razor clam (17.50$33.00 \mathrm{mg} / \mathrm{kg}$ ) were higher compared to the maximum permissible limit established by the FAO (1983) (Table 2). In general, Cd are supposed not be regulated by organism but cumulative uptake can be anticipated.

Similarly, Pearce \& Mann (2006) reported high Cd levels $(0.15-156 \mathrm{mg} / \mathrm{kg})$ in the shells of razor clam (Ensis siliqua) collected from west coast of mainland Britain. In addition, Yap et al. (2008) also reported high concentrations of $\mathrm{Cd}$ in cockle Anadara granosa collected from Kuala Juru, Penang, Malaysia which exceeded Malaysian Food Regulation 1985 and WHO 1988 guidelines limits. The high concentration of $\mathrm{Cd}$ in this case perhaps is due to active industrialization activities within the vicinity of coastal areas. The excessive $\mathrm{Cd}$ ingestion in cockles increased $\mathrm{Cd}$ accumulation, and eventually through bioaccumulation and biomagnification processes, high concentration of $\mathrm{Cd}$ could be found in the human body, who consumes these cockles.

In this study, razor clams of Kuala Selangor possessed Cr ranged from $18.00-42.50 \mathrm{mg} / \mathrm{kg}$ and this level exceeded the FAO (1983) limit. The maximum MTDI of $\mathrm{Cr}$ is $0.1-1.2 \mathrm{mg} / \mathrm{kg}$ and high accumulation of $\mathrm{Cr}$ in human body may cause chronic effects in the lung, liver, kidney and circulatory system (WHO 1988). Among the major sources of $\mathrm{Cr}$ are chromium alloys and chrome plating. Mercury $(\mathrm{Hg})$ was found to be the least abundant among the metals analyzed in this study, which ranged from 0.07 to $0.15 \mathrm{mg} / \mathrm{kg}$. In general, ability to accumulate $\mathrm{Hg}$ varied among mollusks. For example, Kehrig et al. (2006) claimed that green mussel Perna viridis is a better methylmercury accumulator compares to other types of clam and oyster.

In general, high concentrations of heavy metals in razor clam of Kuala Selangor could be related to the existence of various anthropogenic activities. Based on onsite observation during sample collection exercise in August 2007, dominant landscape were the fleet of ships and barges involved in trading of the recycling scrap metals. Based on random short interviews with local people, it was common to see these ships in the area, actively transporting used metals to well-established scrap metal industry located just around the corner.

Table 2. Average concentration (mg/kg dry wt. \pm S. D) of heavy metals in different parts of razor clam.

\begin{tabular}{lccccc}
\hline \multirow{2}{*}{ Organ } & \multicolumn{5}{c}{ Concentration $\mathbf{( m g / k g )}$} \\
\cline { 2 - 6 } & $\mathrm{Cd}$ & $\mathrm{Mn}$ & $\mathrm{Cr}$ & $\mathrm{Fe}$ & $\mathrm{Hg}$ \\
\hline Shell & $33.00 \pm 2.12$ & $82.00 \pm 0.71$ & $42.50 \pm 2.83$ & $59.75 \pm 6.72$ & $0.10 \pm 0.01$ \\
Tissue & $17.50 \pm 3.54$ & $94.00 \pm 2.83$ & $23.75 \pm 4.60$ & $146.50 \pm 2.83$ & $0.07 \pm 0.00$ \\
Foot & $29.50 \pm 3.54$ & $78.75 \pm 3.89$ & $35.75 \pm 4.60$ & $56.75 \pm 2.47$ & $0.07 \pm 0.00$ \\
Siphon & $30.00 \pm 4.95$ & $77.50 \pm 0.71$ & $33.75 \pm 2.47$ & $118.25 \pm 3.18$ & $0.11 \pm 0.01$ \\
Gill & $25.00 \pm 5.66$ & $59.25 \pm 4.60$ & $18.00 \pm 4.24$ & $23.50 \pm 7.78$ & $0.15 \pm 0.01$ \\
FAO (1983) limit & 2.00 & $\mathrm{NA}$ & 1.00 & $\mathrm{NA}$ & 0.50 \\
(ppm wet wt) & & & & & \\
\hline
\end{tabular}

NA: not available 
While transportation of metals between ships, barges and nearby factory, some metals accidently fell into the water (sea) and the workers have no means to retrieve them. Overtime, eventually these areas become contaminated. It is likely the discharge from the factory contains traces of metals, therefore one may say that the factory is one of the contributors to this pollution.

The observed differences in the levels of $\mathrm{Cd}, \mathrm{Mn}, \mathrm{Cr}, \mathrm{Fe}$ and $\mathrm{Hg}$ in different parts of razor clam were tested statistically. The results showed that there were significant differences $(\mathrm{P}<0.05)$ between heavy metal concentrations in different parts of razor clam for $\mathrm{Cd}$ ( $\mathrm{P}=0.001), \mathrm{Mn}(\mathrm{P}=0.001), \mathrm{Cr}(\mathrm{P}=0.008), \mathrm{Fe}$ $(\mathrm{P}=0.001)$ and $\mathrm{Hg}(\mathrm{P}=0.001)$.

\section{CONCLUSION}

Based on morphological data, razor clams inhabiting mudflat area near Kampung Kelanang Kuala Selangor are Solen sarawakensis. However, COI gene sequence data analysis suggested that they merit different scientific name as genetic divergence was $11.7 \%$, yet more studies need to be done in future to clarify its taxonomy status. The heavy metal concentrations $\mathrm{Fe}, \mathrm{Mn}, \mathrm{Cr}, \mathrm{Cd}$ and $\mathrm{Hg}$ showed different accumulation levels in different parts of razor clam. The non-essential elements, $\mathrm{Cr}$ and $\mathrm{Cd}$ recorded in razor clams during this study have exceeded the legal limits stipulated by FAO (1983) and this could be due to anthropogenic activities in Kuala Selangor. However, it is also necessary to study the heavy metal levels in sediment and water column in future to determine the correlation between heavy metals in the razor clams with that of in sediment and water.

\section{ACKNOWLEDGEMENTS}

The authors would like to thank local people of Kampung Kelanang, Kuala Selangor who act as guides and Malaysian Department of Fisheries (Selangor) staff for their help during sample collections in August 2007. Thank you to UNIMAS for supporting staff participations as well as providing laboratory facilities. This study is partially funded by UNIMAS Top Down Research Grant, No: 01(K01)/541/2005(41).

\section{REFERENCES}

Abbott, T. \& Dance, P.S. (1982). Compendium of seashells. E.P. Dutton, Inc., 2 Park Avenue, New York. pp 338-339.

Altschul, S.F., Gish, W., Miller, W., Myer, E.W., \& Lipman, D.J. (1990). Basic Local Alignment Search Tool. Journal of Molecular Biology, 215: 403-410.

Boyden, C.R. \& Phillips, D.J.H. (1981). Seasonal variation and inherent variability of trace elements in oysters and their implications for indicator studies. Marine Ecology Program Series, 5: 29-40.

Bradley, R.D. \& Baker, R.J. (2001). A Test of the Genetic Species Concept: Cytochrome $b$ Sequences in Mammals. Journal of Mammalogy, 82: 960-973.

Bryan, G.W., Langston, W.J., Hummerstone, L.G., \& Burt, G.R. (1985). A guide to the assessment of heavy metals contamination in estuaries using biological indicator. Marine Biological Association of the United Kingdom: Devon.

Cosel, R. von. (1990). An introduction to Razor Shells (Bivalvia: Solenacea). In Morton, B. (Ed). The Bivalvia: Proceedings of Memorial Symposium in Honour of Sir Charles Maurice Yonge, Edinburgh 1986. Hong Kong University Press.

Chen, L.M., Kong, X.Y., Yu, Z.N., Yu, S.S., \& $\mathrm{Xu}, \mathrm{H}$. (2005). Sequence comparison and phylogenetic relationship of mtDNA 16SrRNA and COI gene fragments in three species of razor shell. Marine Sciences, 29: 223-231.

Duquesne, S.J. \& Coll, J.C. (1995). Metal accumulation in the clam Tridacna crocea under natural and experimental conditions. Aquatic Toxicology, 32: 239-253.

Food and Agricultural Organization (FAO). (1983). Compilation of legal limits for hazardous substance in fish and fishery products. FAO Fishery Circular, No. 464, pp. 5-100. 
Grewe, P.E., Krueger, C.C., Aquadro, C.F., Bermingham, E., Kincaid, H.L. \& May, B. (1993). Mitochondrial DNA variation among lake trout (Salvelinus namaycush) strains stocked into Lake Ontario. Canadian Journal of Fisheries and Aquatic Sciences, 7: 2397-2403.

Hassan, R. \& Laiping, F. (2008). Some aspects on socio-economic of razor clam fisheries at Kuching Bay Sarawak. Proceedings of the $5^{\text {th }}$ National Fisheries Symposium 2008, Jabatan Perikanan Malaysia. 87-92 pp.

Hassan, R., Rahim, S. A.K.A., \& Nyanti, L. (2007). Razor clams (Solen spp.) of Kuching Bay, Sarawak, Malaysia. Paper presented at the Conference on Biodiversity: Balancing Conservation and Production Case Studies from the Real World, $26^{\text {th }}-28^{\text {th }}$ June 2007, University of Tasmania, Launceston, Australia.

Hung, T.M. \& Hassan, R. (2007). Application of multivariate techniques in determining morphological variation in Genus Solen of Kuching Bay area in Sarawak. Paper presented at the International Conference at Mathematical Science held in Kuala Lumpur, 28-29 November 2007. Universiti Malaya, Malaysia.

Ji, J., Choi, H.J., and Ahn, I-Y. (2006). Evaluation of Manila clam Ruditapes philippinarum as a sentinel species for metal pollution monitoring in estuarine tidal flats of Korea: Effects of size, sex, and spawning on baseline accumulation. Marine Pollution Bulletin, 52: 447-468.

Kehrig, H.A., Costa, M., Moreira, I., \& Malm, O. (2006). Total and methyl mercury in different species of molluscs from two estuaries in Rio de Janeiro State. Journal of Brazilian Chemical Society, 17: 1409-1418.

Khalid, M,E-M. \& Mohamed, H.Y. (2005). Accumulation patterns of heavy metals in venus clams, Paphia undulata (Born, 1780) and Gafrarium pectinatum (Linnaeus, 1758) from Lake Timsah, Suez Canal, Egypt. Egyptian Journal of Aquatic Research, 31: 13-30.
Kumari, L.K., Kaisary, S., \& Rodrigues, V. (2006). Bio-accumulation of some trace metals in the short-neck clam Paphia malabarica from Mandovi estuary, Goa. Marine Pollution Ecotoxicology, 32: 229234.

Lamprell, K \& Healy, J. (1998). Bivalves of Australia. Volume 2. Backhuys Publishers. Leiden.

Lau, S., Mohamed, M.A., Yen, T.C., \& Su'ut, S. (1998). Accumulation of heavy metals in Freshwater Mollusc. The Science of the Total Environment, 214: 113-121.

MacCarthy, G. (1996). CHROMAS 1.45 program. Queensland, Australia.

Oliver, P.G. (1992). Bivalved Seashell of the Red Sea. National Museum of Wales, Cathays Park, Cardiff CF1 3NP, Wales, U.K, pp 134-136.

Pechenik, J.A. (2000). Biology of the invertebrates. Fourth edition. USA: McGraw-Hill High Education Publication.

Pearce, N.J.G. \& Mann, V.L. (2006). Trace metal variations in the shells of Ensis siliqua record pollution and environmental conditions in the sea to the west of mainland Britain. Marine Pollution Bulletin, 52: 739755.

Rahim, S.A.K.A. \& Hassan, R. (2009). Razor clam fishery in Kuching and Samarahan Division. In Latif et al. (Eds.). Proceedings of International Conference on Marine Ecosystem. Universiti Kebangsaan Malaysia and National Oceanographic Directorate, Malaysia. 156-163 pp.

Rahim, S.A.K.A. \& Tan, C.Y. (2008). Study on the natural stock of razor clams (Family Solenidae in Kuching Bay, Sarawak. Paper presented at the $7^{\text {th }}$ International Annual Symposium on Sustainability Science and Management (UMTAS), 8-10 June 2008, Universiti Malaysia Terengganu.

Rayment, G.E. \& Barry, G.A. (2000). Indicator tissues for heavy metal monitoring additional attributes. Marine Pollution Bulletin, 41: 353-358. 
Rinyod, A.M.R. \& Rahim, S.A.K.A. (2011). Reproductive cycle of the razor clam Solen regularis Dunker, 1862 in the western part of Sarawak, Malaysia based on Gonadal Condition Index. Journal of Sustainability Science and Management 6(1):10-18.

Ruelas-Inunza, J.R. \& Páez-Osuna, F. (2000). Comparative bioavailability of trace metal using three filter-feeder organisms in a subtropical costal environment (Southeast Gulf of California). Environmental Pollution, 107: 737-444.

Tamura, K., Dudley, J., Nei, M., \& Kumar, S. (2007). MEGA4: Molecular Evolutionary Genetics Analysis (MEGA) software version 4.0. Molecular Biology and Evolution, 24: 1596-1599.
Thompson J.D, Gibson T.J., \& Plewniak, F. (1997). The Clustal X windows interface: flexible strategies for multiple sequence alignment aided by the quality analysis tools. Nucleic Acids Research, 24: 48764882.

World Health Organization. (1988). Chromium. Environment Health Criteria. No. 61. Geneva, Switzerland.

Yap, C.K., Hatta, Y., Edward, F.B., \& Tan, S.G. (2008). Comparison of heavy metal concentrations $(\mathrm{Cd}, \mathrm{Cu}, \mathrm{Fe}, \mathrm{Ni}$ and $\mathrm{Zn})$ in the shells and different soft tissues of Anadara granosa collected from Jeram, Kuala Juru and Kuala Kurau, Peninsular Malaysia. Pertanika Journal Tropical Agriculture Science, 31(2): 205-215. 